\title{
ESPELHOS DE SI: \\ BURLE MARX A PARTIR DE SUAS CARTAS
}

\author{
MIRRORS OF THEMSELVES: BURLE MARX THROUGH HIS LETTERS
}

Guilherme Mazza Dourado*

\section{RESUMO}

Breve ensaio sobre as cartas de Roberto Burle Marx como inédita e significativa fonte de conhecimento de sua multifacetada atividade profissional e sua trajetória humana. Este trabalho analisa a correspondência ativa do paisagista-artista, escrita entre as décadas de 1940 e 1990, destinada a familiares, paisagistas, botânicos, horticultores, instituiç̧ões e personalidades destacadas no cenário nacional e internacional da época.

Palavras-chave: Correspondência de Roberto Burle Marx. História do paisagismo. Brasil.

Século XX.

\section{ABSTRACT}

A brief essay of Roberto Burle Marx's letters as a unique and significant source of knowledge on his multifaceted professional activity and his human trajectory. The work analyzes the active correspondence of the landscape architect, written over the decades from the 1940s to the 1990s, and addressed to his family members, landscape architects, botanists, horticulturists, institutions and various well-known people on the Brazilian and international scenes at the time.

Keyworks: Letters of Roberto Burle Marx. History of landscape architecture. Brazil. 20 th. Century.

Dirigindo-se ao suíço-americano Conrad Hamerman, em correspondência de 18/11/1964, Roberto Burle Marx manifestava inquietação quanto à essência e intensidade de seu trabalho. Havia duas semanas que ele se emocionara com um recital doméstico do pianista polonês Miecio Horszowski, que tocou a Sonata n. 32, opus 111, de Ludwig van Beethoven, no sítio Santo Antônio da Bica. E dizia:

Quando ouço obras deste nível, me dá vontade de me esforçar mais, a fim de me expressar de um modo mais profundo e digno; por isso, estou convencido da importância de criar um ambiente, onde a estupidez, o rame-rame diário e a estultice sejam postos de lado para justificarmos um pouco nossa passagem pelo planeta (MARX, 1964).

Ao término de suas trajetórias humana e profissional, os efeitos dessa disposição estavam expressos nos patamares qualitativos e quantitativos alcançados pela sua produção.

\footnotetext{
Universidade de São Paulo, Faculdade de Arquitetura e Urbanismo.

Rua do Lago, 876, CEP 05508-080, Butantã, São Paulo, SP.

CV: http://lattes.cnpq.br/9741632940952403

mazzadourado@uol.com.br
} 
Reconhecido nacional e internacionalmente como um dos pilares da cultura paisagística moderna, Burle Marx é autor de mais de dois mil projetos de paisagismo, distribuídos não somente de Norte a Sul do Brasil como também nas Américas, na Europa e na Ásia. É responsável por um número ainda maior de obras de artes plásticas, entre pinturas, desenhos, gravuras, painéis cerâmicos, esculturas e tapeçarias. Concebeu um elenco nada desprezível em matéria de design de joias, projetos de cenários e figurinos teatrais. $E$, como nenhum profissional antes e depois dele, promoveu uma série importante e pioneira de expedições botânicas - durante mais de cinquenta anos, pelo Brasil adentro - para estudo e coleta de novas espécies com potencial paisagístico

Diante de um personagem assim, sempre ocupadíssimo em seus múltiplos afazeres e compromissos, é surpreendente constatar que ainda encontrasse tempo e ânimo para escrever e ler cartas. E não foram poucas - o acervo preservado em seu escritório supera tranquilamente o volume de 2 mil delas, englobando a correspondência ativa e a passiva. Considerando a extensão desse legado documental e a estatura do profissional em questão, não há nenhum exagero em afirmar que Burle Marx tem presença significativa - até hoje pouco conhecida - no campo da epistolografia brasileira do século XX e, particularmente, entre seus pares paisagistas, inclusive estrangeiros, que raríssimos foram missivistas tão contumazes e asseguraram que suas correspondências chegassem até nós.

Em linhas gerais, o epistolário burlemarxiano é formado por cartas profissionais e pessoais, agrupadas conjuntamente e redigidas principalmente entre as décadas de 1940 e 1990. A maioria da correspondência ativa preservada consiste em reproduções a carbono dos originais datilografados, sendo raras as cópias de manuscritos redigidos pelo próprio paisagista. Talvez em razão da caligrafia de difícil leitura, preferia ditar as cartas para serem datilografadas por secretárias, assistentes, colaboradores, amigos ou mesmo quem estivesse disponível e pudesse ajudá-lo nessa tarefa, seja no escritório, no sítio ou em viagem. Por sua vez, a correspondência passiva abarca originais manuscritos e datilografados e envelopes em que foram remetidos, além de postais, fotografias e outros documentos. É interessante comentar o que eram essas reproduções a carbono, tendo em vista que estão em desuso atualmente. Para gerar uma cópia de arquivo, era costume introduzir na máquina de escrever duas folhas em branco entremeadas por papel carbono - um produto industrial entintado num de seus lados, geralmente em preto, azul, verde ou vermelho, desenvolvido especialmente para obter reproduções. Conforme o teclado da máquina de escrever era acionado, o carbono transferia, por compressão, o que estava sendo datilografado na primeira para a segunda folha em branco. $\bigcirc$ processo era simples e o resultado assegurava uma cópia estável e duradora, bem diferente, por exemplo, do xérox, que perde sensivelmente a nitidez com o passar dos anos.

Os cuidados na preparação das missivas começavam com a escolha do suporte adequado. Personalidade sofística e exigente, Burle Marx tratava para que suas cartas 


\section{ROBERTO BURLE MARX}

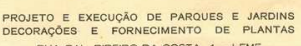

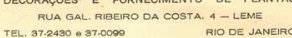

$$
\text { Narch 26, 295ls }
$$

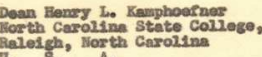

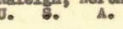

Doese Dean Kasphoerners:

Thank you very weh for your most weleone letter

of Naseh 12. It arrived at a most opportune momont. Sometime ago I was lnvited to hold an exhibit of ny work at the Sersthsomian Institution in Washingtom 作 somian has also lndicatol that the oxisht would be elrav-

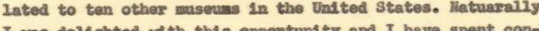
I was dolighted vith this opportanty and I have spent con-

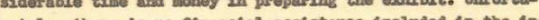
nataly, there 1s no Mnancial assistanco lnoluded in the in-

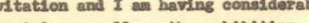
bition.

Friands in the Dinitad States Information Service here are enthusiastie about my golng to the United States and have been most cooperative in trying to help me although there are no United States Governmont funds avaliable for this Jun nose. They have contected the Carden clubs of hmorice to see if a loct

14th this beckground you will undhratand how woll your invitations 11 it into my plans. At one tame I had hopod because of the finenetal problems.

since I and completely unfamiliar urith the contribusince I ain completely unfamilias with the contributions ordinarily given by hwarican schools for such an invithation as yours I think I had best leave the suggestion of the dasinite Pigure up to you. I thinik you are in a botter position to know what a tov months stay in the States togeth

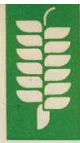

ROBERTO BURLE MARX

Rio de Janeiro, 02 de outubro de 1979

simon Mayo

Roya1 Botanic Gardens

Kew, Richmond, Surre

Th 9 क

BNGLAND

Dear Simon,

Thank you for your good letter in which you gention the visit to Ford Poundation, Mr. James Gardner, in an etempt to ensure its future existence.

It is very kind of you through your director, Dr. Brennan, to write to the Foxd Foundation to this end, through you state that at the moment you 1ack olfficient infor mation about the requirements for the conditions necessary to establigh a Poundation.

t the present these conditions are not quite defined, though staps are being taken, - the employment of a apecialist on plant disesses to prevent the loss of species; plans to incorporzte tha Herbartum Bradeanum into the estate, thus providing the opportunity for hotanists to study plants in the collection. To date the documentation and catsloguing of the plants is not well organised though efforts are being made in this direction; the work of ldentification of gpecies in the collection having been

Graziella M. Barroso - Araceae Nanuza L. Menezes - Velloz

But much more work 1 is neaded in this filld, for as you are aware the collection is by no neans confined to Axaceae, Velloziacese orchidaceae, Bromeliaceas ate., but consiats of a tremendous
Figuras 1 e 2 Versões dos papéis de carta de Burle Marx, utilizados entre as décadas de 1950 e 1970. A marca-símbolo em flor de helicônia foi redesenhada por Koiti Mori, entre 1973 e 1974.

Fonte: Acervo Escritório de Paisagismo Burle Marx. 
fossem escritas sobre papel de seda branco, considerado elegante para a atividade epistolar da época. Sobre esse mesmo papel ou sulfite também branco, eram produzidas as cópias em carbono para arquivamento. A partir de meados da década de 1960, tanto nestas quanto naquelas prevaleceu o uso do papel sulfite. Em alguns casos, as missivas seguiam aos destinatários com um requinte adicional - papel timbrado, cuja diagramação foi modificada e aprimorada no decorrer do tempo, incorporando novos desenhos e alterações em telefones e endereços profissionais do paisagista.

\section{POR QUE GUARDAR?}

Quando se é um missivista copioso, armazenar um volume considerável de cartas próprias e alheias, exercer algum controle sobre ele e conseguir acessá-lo quando necessário pode significar viver entre a cruz e a espada. Exemplo de atitude extremamente pragmática ao defrontar essas questões é Sigmund Freud, autor de 4.899 missivas conhecidas, embora se estime que exista, pelo menos, a mesma quantidade delas esquecidas nas gavetas dos familiares dos destinatários. Carteador disciplinado, não apenas replicava tudo que recebia, mas buscava manter consigo apenas um seleto conjunto de reproduções do que escrevia a outrem. E, para não perder especialmente a memória geral dos conteúdos de suas cartas e dos destinatários a que estavam endereçadas, lançou mão de um minucioso caderno de anotações que dava conta de seu movimento postal. Segundo Mezan (2000, p. 160):

Freud respondia escrupulosamente a toda a sua correspondência: utilizava para isso as horas noturnas, intervalos entre sessões e, principalmente, os domingos. Mantinha igualmente um registro, atualizado a cada dois ou três dias, em duas colunas: cartas recebidas e cartas enviadas. Ao lado do nome do destinatário e da data, colocava um resumo de duas ou três linhas para referência futura, por exemplo se uma dada missiva se extraviasse no correio.

Mas nem todos conseguiram ou quiseram ter organização e desprendimento equivalente ao do 'pai da psicanálise' em relação ao corpo principal de seus papéis - caso de Burle Marx. Mesmo com as mudanças de endereço de seu escritório, o paisagista buscou manter se não todas, pelo menos a parcela principal de sua correspondência ativa e passiva, organizada sem essa distinção em mais de cinquenta pastas-fichário.

À medida que sua firma de projetos crescia e a rotina profissional se tornava mais complexa, houve a necessidade de estabelecer um sistema de classificação para armazenar e consultar de modo ágil e a qualquer tempo as missivas. Esse sistema foi implementado por Guilherme Siegfried Marx, conhecido como Sieg, irmão casula, sócio e administrador do escritório do paisagista, mantido por anos a fio pelas secretárias que por lá passaram, como Yeda, Marília, Fátima Kamagusko, Maria Amália Manasfi e Maria Aparecida Guerra, entre outras. Em linhas gerais, consistia no agrupamento 
das cartas segundo os países e os estados brasileiros onde viviam os destinatários e em ordem temporal decrescente, para facilitar a incorporação das mais recentes sem ter que retirar do lugar as que já estavam arquivadas.
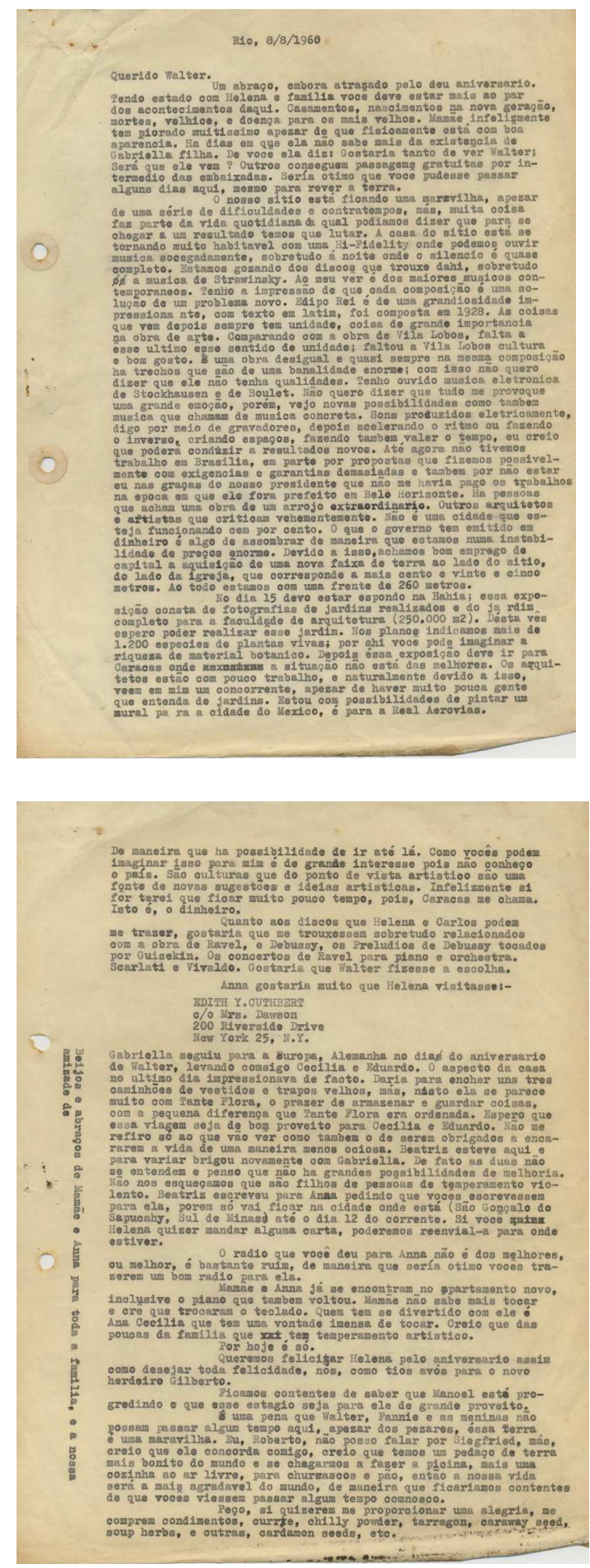

Figuras 3 e 4 Carta para Walter Burle Marx, de $8 / 8 / 1960$.

Fonte: Acervo Escritório de Paisagismo Burle Marx. 
Afora esses conjuntos geográficos, havia pastas específicas para um mesmo destinatário, cuja correspondência era mais intensa (e, por isso, volumosa) - caso de Walter Burle Marx, irmão mais velho radicado nos Estados Unidos, e de Conrad Hamerman, paisagista, colaborador e amigo de Roberto, nesse mesmo país. Apenas a título de ilustração, as seis pastas de Walter contêm nada menos do que 559 cartas, entre correspondências enviadas e recebidas. Após o falecimento do paisagista, em 1994, o acervo epistolar foi legado a Haruyoshi Ono, seu sócio e discípulo, e atualmente vem sendo mantido sob a supervisão de Fátima Gomes e Isabela de Carvalho Ono, na atual sede do escritório Burle Marx, no bairro de Laranjeiras, Rio de Janeiro.

É claro que nada disso fora produzido tencionando-se o conhecimento geral e a publicação, ao menos quando o paisagista estava em franca atividade e se empenhava na difusão de seus projetos, entrevistas e escritos teóricos no Brasil e no exterior. Certamente isso explica o porquê Burle Marx nem cogitou, em vida, a veiculação de suas cartas, e preferiu editar suas palestras no livro Arte e paisagem: conferências escolhidas, convencido pelos esforços do também sócio e discípulo José Tabacow, organizador do volume que saiu em 1987. No entanto, hoje a sua correspondência é tão importante quanto suas conferências para um entendimento mais completo de sua vida e de sua obra. É bem possível que o paisagista compartilhasse da mesma opinião de Machado de Assis, que, em seus últimos meses de vida, aquiescera ao pedido de José Veríssimo, dando-lhe uma reticente permissão para agrupar e editar seu conjunto epistolar:

Não me parece que em tantas cartas que escrevi a amigos e estranhos se possa apurar nada de interessante, salvo as recordações pessoais que conservarem alguns [...] O tempo decorrido e a leitura que fizer da correspondência lhe mostrará que é melhor deixá-la esquecida e calada (ASSIS, 1908 apud ROUANET, 2008, p. VII).

Mas as reservas do nosso maior escritor oitocentista não se justificavam e tampouco impediram o reconhecimento do enorme valor do seu legado epistolar em seu próprio tempo e ainda hoje. A correspondência machadiana segue disponível e justificando novas edições, sendo a mais recente e completa delas em cinco alentados volumes, publicados a partir do centenário de seu falecimento, em 2008, pela Academia Brasileira de Letras (ABL).

\section{CARTAS AO MUNDO}

Por que Burle Marx, que possuía os dias tão preenchidos por diversas atividades, compromissos e viagens, se ocupava também em mandar cartas? Por que, em algumas situações, ele resolvia alongar a conversa com quem acabara de falar do outro lado do mundo, por telefone, escrevendo-lhe uma correspondência? Há várias possibilidades de entendimento para essas indagações que buscam sondar o anseio carteador do paisagista. Mas certamente um bom ponto de partida é situar Burle Marx no contexto 
das derradeiras gerações de intensos missivistas para as quais o diálogo por carta abrangia um leque de múltiplos significados, envolvendo desde a simples prática de comunicação até a arte de cultivar a civilidade. Para esses grupos, o exercício do carteio podia atingir a um tal estágio em que há menos de pura compulsão pela escrita e muito mais de alta polidez e amizade. Nas certeiras palavras de Resende: "Não é grafomania. É civilidade." (RESENDE 2011, p. 232). Daí porque a escrita de cartas se manteve viva e incessante entre essas pessoas, mesmo quando surgiram outros modos revolucionários de cambiar informações à distância em seu tempo, como o telégrafo e o telefone.

Burle Marx se correspondia com um rol variado de personagens e instituições pelo Brasil e por todos os cantos do planeta. Escrevia para nomes de destaque e vidas comuns, para familiares e amigos, para sócios e colaboradores de seu escritório, para antigos e novos companheiros de ofício, para pequenos comerciantes e organizações renomadas. Em resumo, carteava com muita gente e não apenas em português, mas também em alemão e inglês. Dominava perfeitamente sua língua materna e o idioma germânico apreendido no convívio com seu pai. Como todo missivista, praticava dois pesos e duas medidas no momento de dirigir-se aos destinatários. Com os estranhos, era formal e reservado; com os mais próximos, sentia-se à vontade para falar de tudo.

Entretanto, havia um claro diferencial na hora de endereçar cartas mais longas, detalhadas e com certa frequência, que seguiam para um círculo diminuto de pessoas, com o qual mantinha relações profissionais ou sólidos laços de amizade. Aos sócios, colaboradores e funcionários do escritório, as correspondências fluíam quando o paisagista estava viajando e cobrava notícias, e sobretudo quando manteve uma filial de seu estúdio de projetos em Caracas, na Venezuela, entre as décadas de 1950 e 1960. Nesse caso, eram encaminhadas aos seus sócios - o paisagista inglês John Stoddarte o paisagista chileno Fernando Tábora. Ao contatar grandes amigos que habitavam no exterior, Burle Marx buscava apagar as distâncias e fazer-se presente por meio das folhas escritas. Não apenas tidas na mais alta estima, essas amizades eram consideradas por ele seus familiares eletivos. "Não há dúvida que você é mais parente meu que os meus próprios parentes. Espero ter a possibilidade de tê-lo como amigo até o fim do período transitório que é a nossa vida na terra, se é que existe outra vida" - assinalava em carta de 20/8/1965 ao decorador e colecionador pervano Alex Ciurlizz. Nesse grupo figuravam igualmente Walter, seu irmão mais velho e alma gêmea; o braço-direito nos EUA e paisagista suíço-americano Conrad Hamerman; o paisagista cubano Gabriel Berriz e o paisagista colombiano Alfonso Leiva Galvis, entre outros.

\section{REVENDO UMA TRAJETÓRIA}

Um turbilhão de assuntos perpassava a correspondência de Roberto Burle Marx, cuja leitura hoje permite recompor, com impressionante riqueza de detalhes, os prin- 
cipais episódios de sua vida profissional e pessoal entre as décadas de 1940 e 1990, ou seja, o período central de sua maturidade intelectual e profissional. As missivas compartilham realizações presentes e planos futuros, projetos concluídos e obras em processo, sucessos e infortúnios, alegrias e tristezas, ironias e críticas, opiniões e incertezas, felicidade e cólera no ambiente familiar, progressos e dificuldades financeiras, coisas simples e magníficas da existência, fatos políticos e episódios cotidianos, teorias artísticas e filosofias de vida, e muito mais. Porém, existia uma clara fronteira estabelecida pelo grau de distância ou intimidade com o destinatário, e, consequentemente, nem tudo era dito a todos. Nas cartas profissionais, as notícias estavam circunscritas fundamentalmente às questões de trabalho, aos andamentos, impasses e perspectivas relacionados a ele. Já nas missivas pessoais, a narrativa corria solta, especialmente quando se privava da confiança e da amizade com o interlocutor para o qual as linhas estavam endereçadas. Tanto nestas quanto naquelas, há um caudal de informações que possibilita visualizar um perfil intenso de Burle Marx. Elas contêm passagens surpreendentes em que o paisagista-artista compõe um retrato irreverente, mas expressivo de si e da vida, pelo qual deixa conhecer traços importantes de sua personalidade, com seu senso de humor, sua imaginação transbordante e sua especial percepção de tempo e lugar onde habitava e circulava. Assim ele falava na correspondência ao paisagista uruguaio Leandro Silva Delgado e sua esposa Júlia, em 7/11/1979:

Estou thes escrevendo depois da maravilhosa estadia na Espanha, onde absorvi tanta maravilha que quase tive uma indigestão de beleza. A companhia de vocês, como também dos seus amigos me fizeram um bem enorme... Madri, Segovia, Toledo, La Granja, a mulher barbada e o estranho desejo lúbrico de dois maridos, a verdade, é que essa estranha mulher conseguiu dois maridos e lá sei se outros não tiveram também o mesmo desejo de experimentar essa fruta tão rara [na forma de] mulher barbada. Estou convencido que ninguém deve desanimar na vida; um pé doente sempre encontra um chinelo velho. Enfim, essa Espanha de paixões indomáveis, de sadismos irrefreáveis, com bobos da corte, monstros e anões, com 'majas desnudas' e vestidas, com duques d'Alba, ex-padres e ex-sacerdotes desbatinados, ou melhor, sem batinas, com duquesas bailarinas saracoteando e tocando castanholas com dentaduras de aço, com 'amor brujo escaldente', [por tudo isso] compreendo muito bem que vocês tenham se arraigado a essa terra. Porém, senti, de uma vez por todas, que minha alma, que meu corpo, que minha mente, fazem parte da floresta com índios e flechas envenenadas, com lacraias, centopeias, serpentes envenenadas, formigas tanajuras e aranhas caranguejeiras, mulatas azuis, verdes e roxas, pivetes enterrando canivetes no ventre das grávidas e calor criando bolor e coceiras nas senhoras que usam tangas de índias, deixando a mostra grandes bundas, onde a bandas se separam apenas por fio de linha. Você compreende que minha vida está ligada a essa terra que apodrece e se renova com a música que vem dos esgotos dos morros e das casas que desabam com o estrondo, ao som das chuvaradas. 
Em outra ocasião, o paisagista revelava mais algumas características de seu modo de pensar e agir. Mesmo quando a saúde dava sinais de alerta, ele não se melindrava, aproveitava para fazer piada de si e lançava previsões sobre o que lhe aguardava como destino final. Registrou o seguinte em correspondência ao irmão Walter e sua esposa Fannie, em 31/1/1968:

Tenho que continuar meu tratamento pulmonar; porém, agora apareceu-me mais um parafuso solto na velha carcaça - açúcar. Dizem que é melhor a gente ser doce do que amargo; porém, preferiria nenhuma das duas coisas. Levarei minha cruz com galhardia e estoicismo. Já escolhi o lugar da minha sepultura: no sítio, debaixo de uma árvore frondosa. Quero me transformar em árvore, na qual cada dedo terá uma floração violenta e sentirei o vento, a tempestade e os relâmpagos a me iluminar. Assim, minha perpetuação se fará. Porém, não vamos chorar antes do tempo. Não quero choro nem vela, nem fita roxa com letras amarelas. Espero ser um defunto enxuto. Depois de morto não quero que me submetam à visitação pública e amigos dizendo: "era tão bom, morreu que nem um passarinho". Quero morrer como um leão, rosnando, lutando e, se possível, destruindo meus inimigos.

\section{PROJETOS DE VIDA}

Há uma gama diversificada de temas abordados nas cartas, mas alguns, em razão de sua especial relevância, merecem mais atenção. Um deles diz respeito ao sítio Santo Antônio da Bica, hoje Roberto Burle Marx, obra-chave que figurou no centro das atenções do paisagista desde a aquisição, em 1949, até o seu falecimento, em 1994. É um dos assuntos mais presentes, que atravessa praticamente de um extremo a outro o conjunto epistolar.

Como um diário de obras, as missivas dão a conhecer as sucessivas transformações e os visitantes que estiveram nesse centro de estudo, cultivo e reprodução de plantas ornamentais, cobrindo especialmente o período de 1955 a 1990. Elas relacionam todo tipo de iniciativa em andamento e programada: a recuperação inicial da casa-sede, a compra de terras para dilatar a propriedade, a formação da coleção de plantas, as novas espécies oriundas das expedições botânicas, o intercâmbio e a aquisição de plantas tropicais com horticultores estrangeiros, as modificações nos viveiros, as dificuldades de cultivo, os problemas na contratação de horticultores e mão de obra treinada, os botânicos que colaboravam na identificação dos exemplares do acervo vegetal, os planos para a construção do ateliê, as primeiras ideias sobre a criação de uma fundação ou parcerias destinadas a colaborar na gestão do sítio.

Era tamanho o zelo e a preocupação de Burle Marx com o presente e o futuro do sítio que, às vésperas de uma longa viagem internacional, decidiu encaminhar uma precaução legal, informando-a para Walter em carta de 16/6/1970. Prestes a expor na $35^{a}$ Bienal de Veneza, providenciou um testamento que tratava do destino da proprie- 
dade e remeteu cópia deste ao irmão. Esse documento é particularmente significativo para rastrear as origens da decisão de transformar o sítio numa fundação ou vinculá-lo a uma instituição sólida, que assegurasse sua permanência no correr do tempo, algo que demorou ainda mais quinze anos para concretizar-se. Em 1985, Burle Marx selou a doação do sítio ao governo brasileiro, esperando ter alcançado certa estabilidade e segurança. Mas nem bem se passaram cinco anos, um balde de água fria minava suas expectativas. A extinção da Fundação Pró-Memória, à qual o sítio estava subordinado, colocou sob ameaça de desmantelamento toda a equipe de funcionários que cuidava das plantas, conforme explicava a Conrad Hamerman em correspondência de 26/3/1990. Enfim, o contato com esses papéis revela os esforços desmedidos e, muitas vezes, com lances épicos, que deram suporte à implantação e à manutenção do sítio.

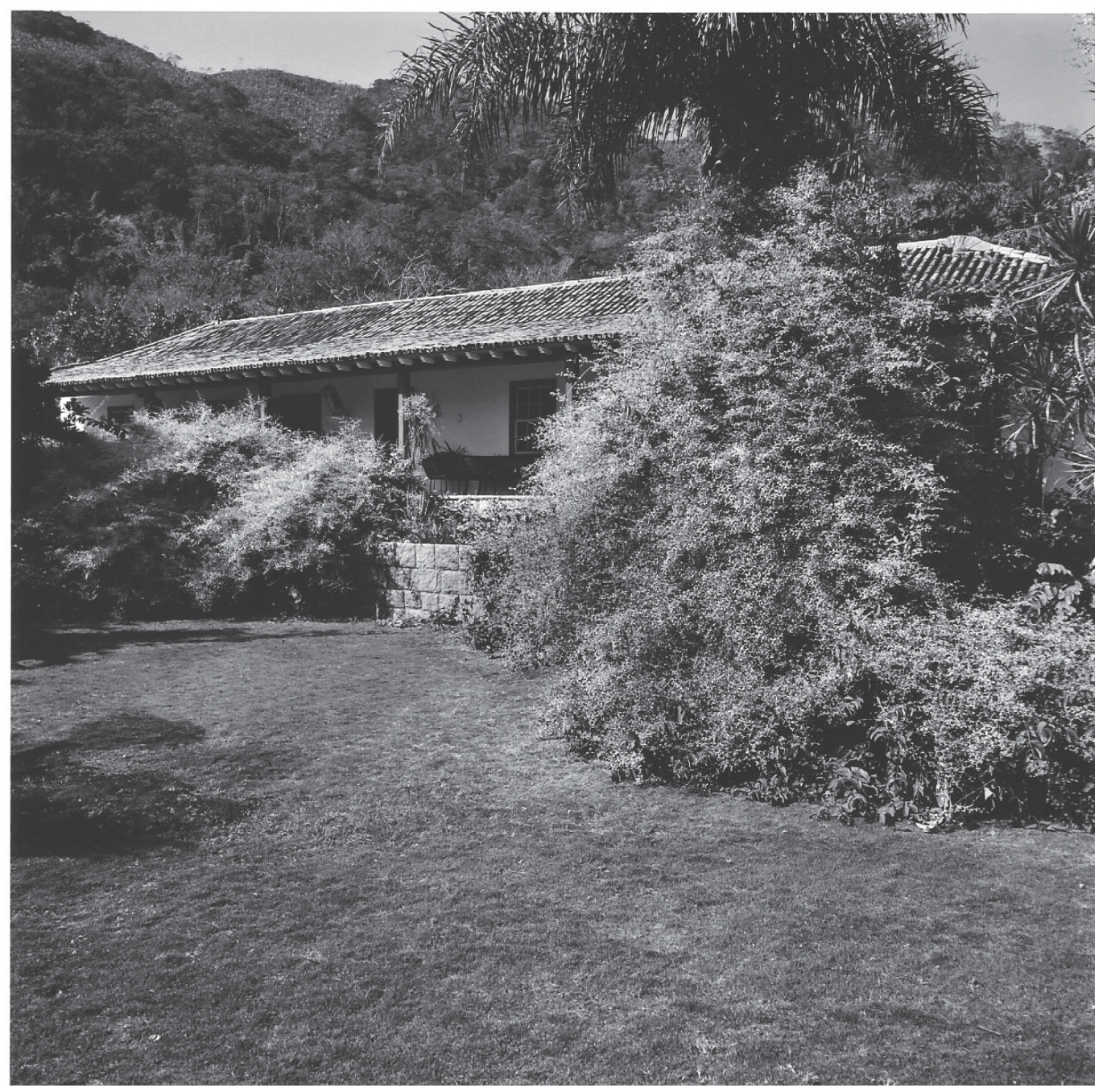

Figura 5 Início da formação dos jardins ao redor da casa principal do sítio Santo Antônio da Bica. Fotos: Marcel Gautherot, década de 1960, Instituto Moreira Salles. 


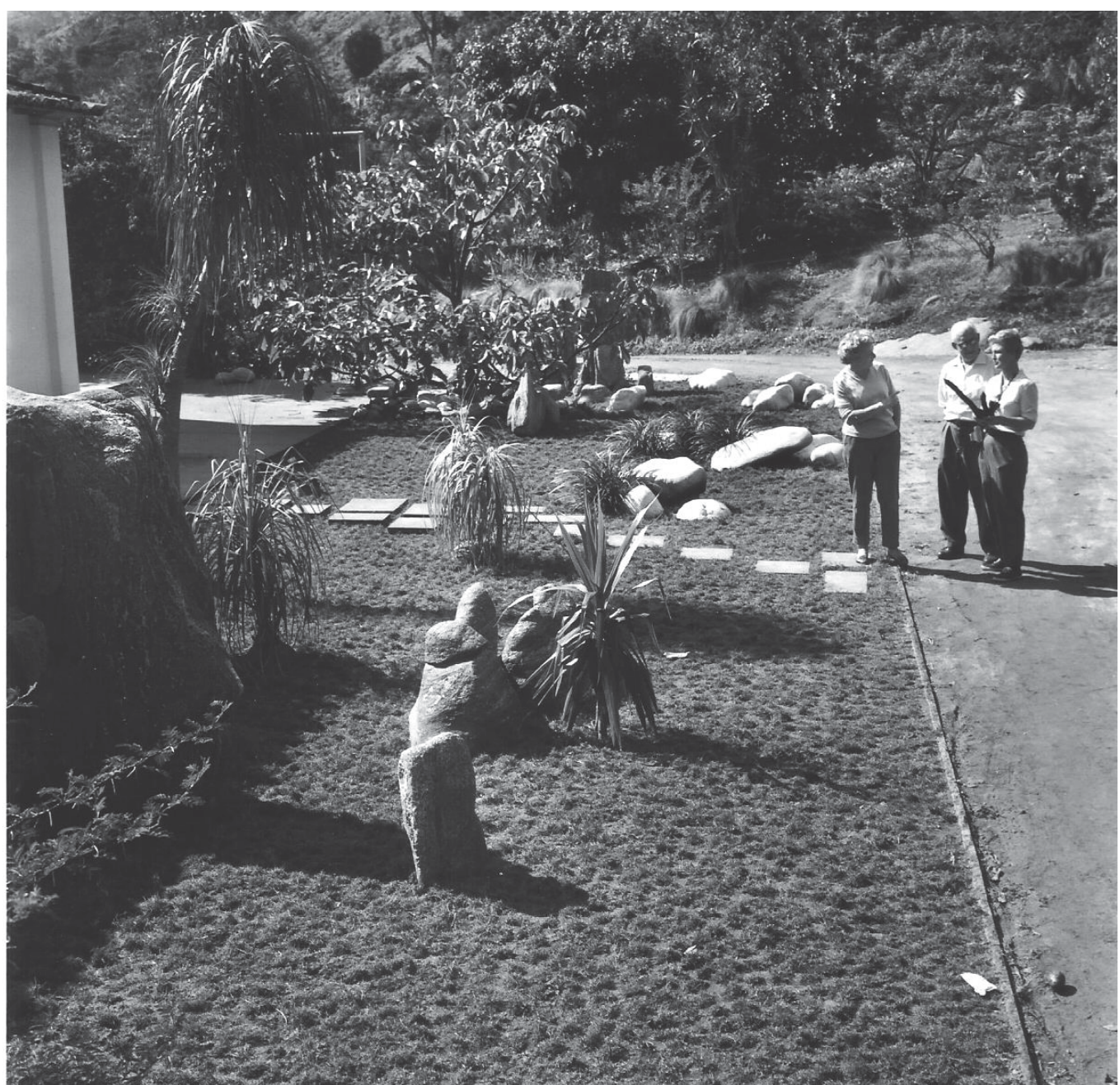

Figura 6 Início da formação dos jardins ao redor da casa principal do sítio Santo Antônio da Bica. Fotos: Marcel Gautherot, década de 1960, Instituto Moreira Salles.

As expedições botânicas são outro tema presente na correspondência do paisagista, que encerra um dos mais significativos registros documentais sobre elas. Com duração de alguns dias ou semanas, envolvendo um grupo restrito ou maior de integrantes paisagistas, botânicos, agrônomos, horticultores, arquitetos, jardineiros e diletantes -, cobrindo uma área específica ou várias regiões, essas excursões de pesquisa e coleta de espécimes para fins paisagísticos asseguravam a Burle Marx refinar seus conhecimentos sobre a flora brasileira no contato direto com ela e davam suporte essencial à ampliação das coleções do sítio, com o ingresso de matrizes para serem aclimatadas e multiplicadas. Segundo se depreende das cartas, as viagens se intensificaram entre as décadas de 1950 e 1960, e tiveram como um de seus pontos altos a expedição do Rio de Janeiro ao Amazonas, em 1983, uma das poucas em que o paisagista não financiou integralmente as despesas do próprio bolso. 
De modo geral, as excursões concentravam-se nos vários biomas da faixa tropical do Brasil, palmilhando regiões conhecidas ou intocadas e, em algumas situações, indo e voltando às mesmas localidades após certo intervalo de anos. Em 1955, esteve-se na Bahia, percorrendo Ilhéus, Itabuna, Caravelas, Alcobaça, incorporando à bagagem duas novas espécies de helicônias, afora antúrios e filodendros. Uma década mais tarde, em 1965, seguiu-se para Minas Gerais e Bahia, passando por Belo Horizonte, Congonhas do Campo, Diamantina, Milagres, Lençóis, Palmeiras e Morro do Chapéu. A região de Goiás Velho foi objeto de visita em 1967, com retorno em 1972. A faixa ao longo da estrada Brasília-Ceará mereceu uma viagem específica, em 1967, onde foram localizadas espécies aquáticas não catalogadas pela ciência. Voltou-se novamente a Minas Gerais e Bahia em 1968. No mesmo ano, circulou-se por Angra dos Reis e Parati. Em 1977, foi a vez do vale do rio Pancas, no Espírito Santo. Em 1978, andou-se pelo Pantanal, em Mato Grosso. Contudo, a série de expedições não se esgotava aí.

Para Burle Marx, o interesse pelo valor sensível da flora, o maravilhamento em face da riqueza e diversidade vegetal e o reconhecimento da natureza como patrimônio da sociedade brasileira eram motivos por si só para ultrapassar toda sorte de entraves, sobretudo no que diz respeito ao deslocamento, alimentação, hospedagem e privação de confortos mínimos durante e após os trabalhos de campo. Em missiva a Walter, de $2 / 5 / 1977$, exemplificava esse quadro de dificuldades, ressaltando o que, de fato, the interessava:

Gasta-se muitíssimo e as condições de higiene são muito precárias, com banheiros e latrinas que lembram a Nigéria. A comida está em razão direta [da distância] das capitais; quanto mais longe, se come menos; porém, o importante é conhecermos melhor esse interior, a fim de tirar o maior proveito das observações que fazemos a respeito da paisagem, como também em relação à vegetação.

Mas, se grande parte dos obstáculos materiais poderia ser driblada, houve um fato que se mostrou intransponível, deixando profundas marcas de tristeza na alma do paisagista. Foi a trágica morte do amigo e arquiteto Rino Levi, vitimado por um ataque cardíaco fulminante durante a excursão a Minas Gerais e Bahia, em 1968. Essa perda The casou tamanho choque e sofrimento, que motivou comentários em quatro cartas para destinatários diferentes: a Walter, em 12/10/1965 (DOURADO, 2009, p. 73-75); a Meta Schück, em 12/11/1965; a John Stoddart e Fernando Tábora, em 17/11/1965; a Alex Ciurlizza, em 12/1/1966.

\section{DEFESA AMBIENTAL}

À medida que o paisagista mais e mais viajava pelo Brasil, ampliava sua percepção de uma realidade calamitosa que grassava pelo território nacional: a destruição 
do ambiente natural. Trata-se de assunto também frequente em sua correspondência, que merece estudo aprofundado, tal a importância e o ineditismo que representa no conjunto das avaliações feitas sobre sua obra. Muito se conhece sobre o paisagista e o artista Burle Marx, mas praticamente nada a respeito de sua atuação como crítico e defensor ambiental, que escrevia protestando aos jornais, dava entrevista e cobrava publicamente as responsabilidades de governantes e empresários. É bem provável que essa tomada de consciência tenha aflorado no início de sua prática de viajante em busca de espécies e no convívio próximo com botânicos desde meados da década de 1930. O certo é que sua correspondência encerra diversos comentários sobre o processo de ruína ambiental de várias localidades do país a partir de 1955. Após voltar de uma excursão de uma semana pela Bahia, onde esteve em Ilhéus, Itabuna, Caravelas e Alcobaça, o paisagista escreveu para Walter, em 18/8/1955, manifestando preocupação pelo que tinha visto: "A verdade é que estão destruindo nossas matas, não havendo reflorestamento. Isso acarretará prejuízos incalculáveis para o futuro." E a indignação retornava, falando também a Walter, em carta de 13/9/1967, sobre o quadro aterrador de uma área a cerca de 300 quilômetros de Brasília:

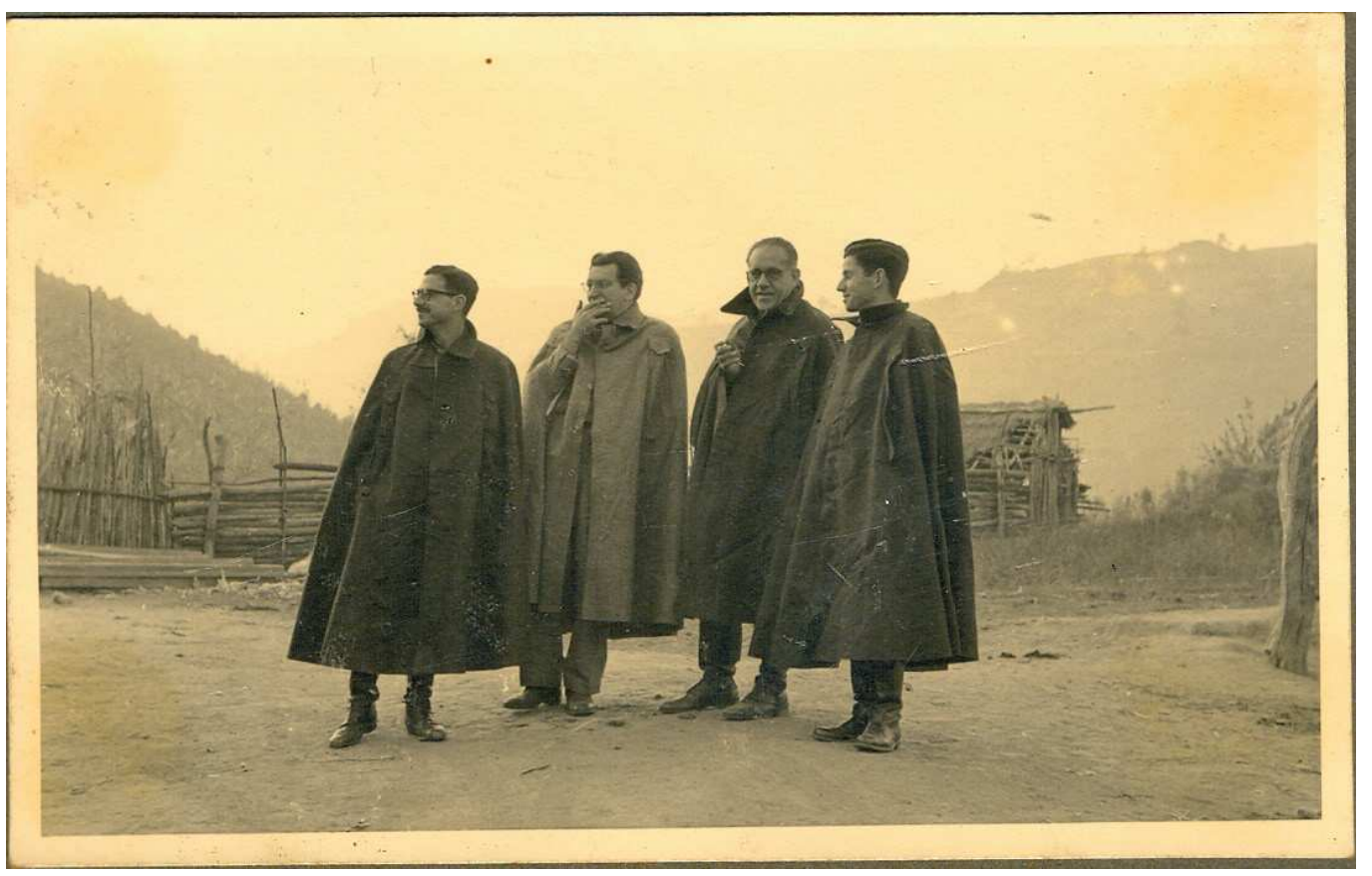

Figura 7 Roberto Burle Marx e Rino Levi em uma das várias expedições botânicas que fizeram juntos. Da esquerda para direta: Cândido Procópio Ferreira de Camargo, Roberto, Rino e Severo Gomes, provavelmente na serra da Bocaina, segundo Malu Gomes.

Fonte: Acervo Escritório de Paisagismo Burle Marx.

As gramíneas do primeiro plano, esturricadas, de tonalidade cúprea, o calcário de tonalidade cinza-azulado escuro. O céu de um azul-cinzento turvo, com o sol pendurado na galharia. Sol vermelho devido à bruma decorrente das imensas queimadas 
que lavram por esse interior afora. Às vezes, tenho a impressão que estou vivendo num país de pesadelos, pois a incompreensão é quase geral. Aceitam esse flagelo como fato consumado e o número de pessoas conscientes dessa destruição é tão pequeno que assombra qualquer um. Estão cortando as aroeiras para servirem de postes em São Paulo. Sairia mais barato se fossem feitos em concreto. Com isso, estão dizimando uma das árvores características do solo calcário do Brasil.

Mesmo nos anos de chumbo da ditadura militar, quando as manifestações críticas nas mais diferentes esferas da sociedade brasileira foram coibidas, Burle Marx seguiu denunciando as mazelas ambientais, inclusive como membro do Conselho Federal de Cultura (CFC), cargo que exerceu entre 1966 e 1974. Ao desligar-se da instituição, formalizando pedido de afastamento em correspondência de 7/5/1974, não deixou de tocar na questão, ressaltando-a como uma farsa do avanço civilizatório nacional e apontando seu dissabor por ser ignorado:

Procedi dezenas de excursões para observar a flora brasileira nativa e, de quase todas, voltei aterrorizado com a destruição maciça, com a extinção de espécies e com a desfiguração da paisagem. Os que depredam e mutilam nosso acervo e nossa natureza se justificam em nome do progresso e do desenvolvimento, como se fosse de todo impossível praticá-los sem a consequência do desastre. Esses equivocados desejam o pleno consentimento para seus abusos e, se alguém discorda e os denuncia, logo agridem com a pecha de antidesenvolvimentista. Não temo ser injuriado pelos depredadores que eu denuncio. Sinto-me, todavia, frustrado quando reconheço a inoperância, a inocuidade das minhas palavras, ainda mesmo quando proferidas da tribuna de maior responsabilidade cultural do país, que é este Conselho, e na qualidade de membro indicado por dois Governos da Revolução Brasileira. Meu compromisso jamais foi o silêncio perante os erros. Meu dever sempre o entendi na luta pela razão. Aqui cabe comentar que conceituo razão como equivalente de experiência, de conhecimento através da experiência e, por isso, que me refiro ao volume de uma extensa e demorada observação pessoal, em botânica e ecologia, quando indico a razão de um procedimento conservador relacionado com a natureza.

Dois episódios centrais na batalha pela conscientização e preservação ambiental empreendida por Burle Marx foram seu discurso no Senado Federal, em junho de 1976, e o embate público e por carta que manteve, no mesmo ano, com Wolfgang Saver, presidente da Volkswagen do Brasil. A detalhada e crítica radiografia sobre o caos ambiental brasileiro exposta ao Senado não poupou nada e ninguém, mas também não se isentou de vislumbrar saídas para os problemas apontados. Nessa apresentação, o paisagista tocava no então recente problema causado pelo dirigente da fábrica alemã de automóveis. Tencionando a ampliação e a diversificação dos negócios brasileiros da empresa que comandava, Saver investiv em um imenso projeto pecuário de 140 mil 
hectares no sul do Pará e, para iniciar a abertura de áreas para pastagens, autorizou uma extensiva queimada florestal. A amplitude do fogaréu chegou a tal ordem que causou assombro nos técnicos da National Aeronautics and Space Administration (NASA) ao observarem as fotos produzidas pelo satélite Skylab. Não demorou para que a imprensa mundial noticiasse o maior incêndio florestal já documentado por imagens de satélite. Na missiva endereçada a Saver, de 4/11/1976, Burle Marx resumia sua completa indignação com o desatino da iniciativa e a permissividade legal para que ocorresse:

[...] mais me interessa ocupar meu tempo tentando convencer, conscientizar ou alertar as autoridades, pois só elas são capazes de mudar leis monstruosas como estas que permitem a grupos realizar, em nome de suas ideias sobre progresso, genocídios que em outros países seriam punidos com a cadeia, do que me apressar a responder a $V$. Sa. que, de antemão, afirma que, nos próximos anos, queimará área seis vezes maior do que aquela que já queimou. Em seguida, V. Sa. diz que o fogo usado na ocasião atingiu exclusivamente arbustos, ervas daninhas e outros tipos de mato, jamais árvores. Não acredito em fogo amestrado. Além de 'ervas daninhas', deve ter queimado também araras 'barulhentas', tatus 'imundos', onças 'ferozes', cobras 'peçonhentas', sem dúvida, árvores de grande porte e talvez até mesmo algum índio 'traiçoeiro'.

\section{ALÉM DAS FRONTEIRAS}

A correspondência de Burle Marx é reveladora de contatos e diálogos internacionais que ainda são desconhecidos tanto dos pesquisadores de sua obra quanto dos estudiosos dedicados à história do paisagismo brasileiro. Nesse caso, uma série especialmente significativa é a formada por missivas remetidas a paisagistas, arquitetos, urbanistas e artistas que integravam a nata da cultura norte-americana do segundo pós-guerra. A leitura desse segmento possibilita relativizar uma certa versão que localiza São Paulo na vanguarda de uma aproximação com a inteligência paisagística dos Estados Unidos, mediada sobretudo por Roberto Coelho Cardozo e sua esposa, Susan Osborn. Aliás, esses mesmos documentos precisam detalhes da transferência ao Brasil desse paisagista luso-californiano, que, tempos depois, se distinguiu como mentor de algumas gerações de profissionais paulistas. Em resposta à Garrett Eckbo, que se empenhou pessoalmente nas articulações para a transferência de Coelho Cardozo ao Brasil, Burle Marx informava em 8/4/1950:

Muito obrigado por sua [carta] de 3 de março. Ainda não tive notícias de seu amigo Roberto Coelho Cardozo, mas certamente terei grande prazer em encontrá-lo e fazer por ele tudo o que estiver ao meu alcance. Ele pareceu-me muito interessante. Farei o possível para que veja tudo o que for significativo e, naturalmente, também gostaria de conhecer o trabalho dele, que parece ser excepcional, considerando a 
descrição que o senhor me fez.

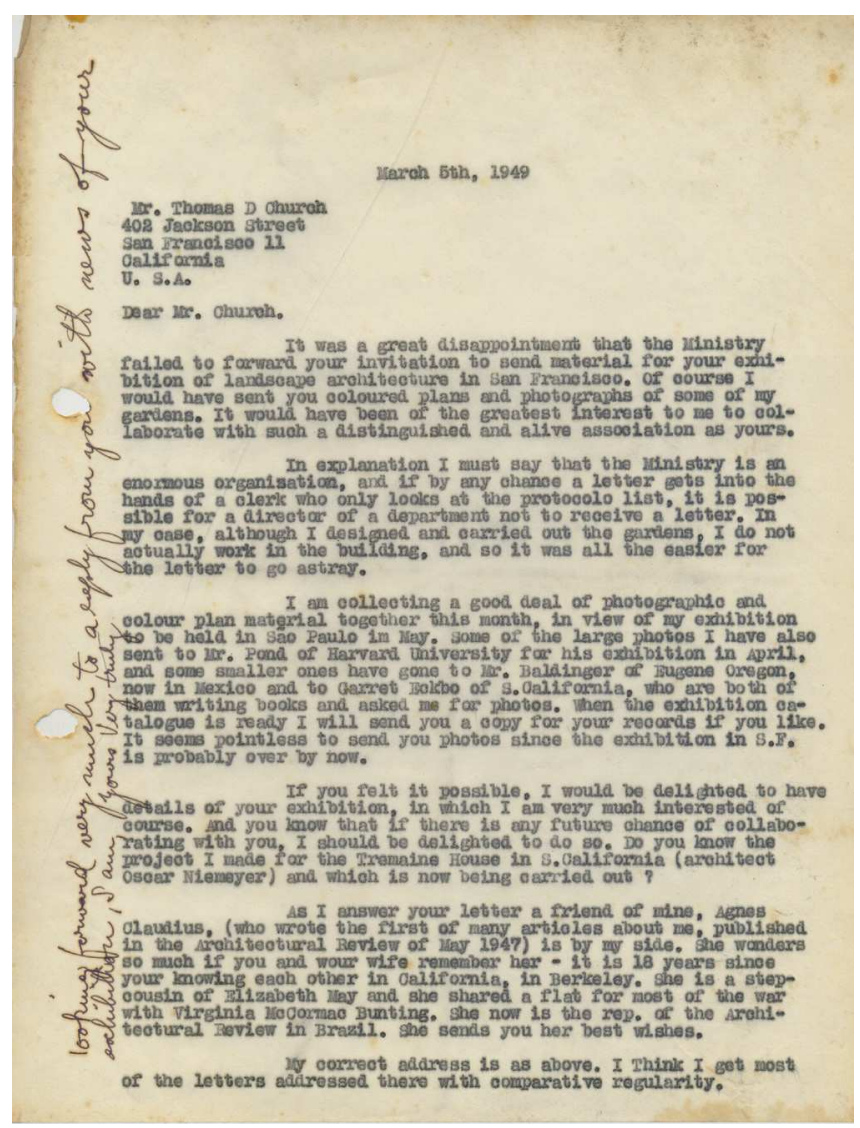

Figura 8 Carta para Thomas Church, de 5/3/1949.

Fonte: Acervo Escritório de Paisagismo Burle Marx.

Analisando-se o conjunto epistolar, vê-se que as ligações de Burle Marx com os norte-americanos já estavam em curso antes da vinda de Coelho Cardozo. Uma das primeiras missivas endereçadas aos paisagistas dos EUA foi uma resposta, em 5/3/1949, ao convite de Thomas Church, para que Burle Marx participasse de uma mostra de paisagismo moderno no The Museum of Modern Art (MoMA), em San Francisco. Decolaram com algumas correspondências trocadas com Garret Eckbo a partir da mesma data. E se alargaram, a partir de 1954, envolvendo também Josep Lluís Sert, Lawrence Halprin, Eero e Aline Saarinen, Richard Neutra, lan McHarg, Francis Violich e outras personalidades. Nessa aproximação, certamente foi decisiva a sua primeira viagem aos EUA, em 1954, para a abertura da exposição itinerante Landscape architecture in Brazil: Roberto Burle Marx, em Washington, resultante de uma promoção conjunta da União Pan-Americana e da Smithsonian Institution - levada depois a nove cidades dos EUA. Nos anos seguintes, há que se considerar as sucessivas visitas que fez ao seu irmão Walter, radicado na Filadélfia, ocasiões em que Burle Marx não apenas circulava pelos ambientes profissionais, mas ministrava frequentemente conferências em 
instituições como Harvard University, North Carolina State University, American Society of Landscape Architects (ASLA), Longwood Gardens, Cornell University, Pennsylvania University, Pennsylvania Horticultural Society, University of San Francisco, University of California, conforme é possível acompanhar pelas cartas.

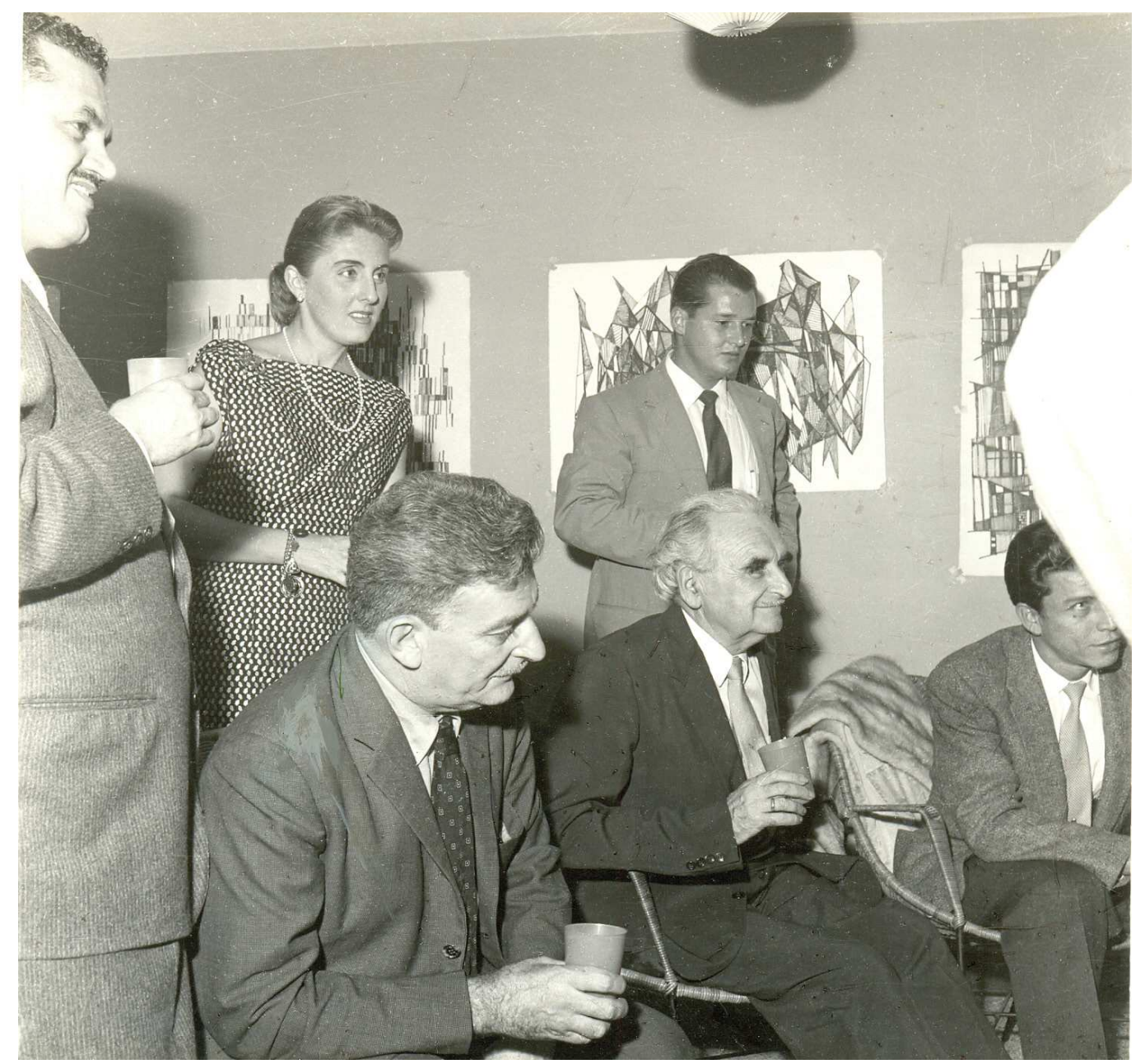

Figura 9 Burle Marx, ao lado de Richard Neutra, no escritório do paisagista em Caracas, meados da década de 1950.

Fonte: Acervo Escritório de Paisagismo Burle Marx.

De fato, os laços com personagens e com a cultura norte-americana, somados à divulgação de matérias sobre seu trabalho em revistas especializadas, jornais e semanários de grande tiragem - caso de The New York Times e The Life Magazine -, ilustram parcela da teia de ligações que Burle Marx cultivou nos Estados Unidos e, de outro lado, a receptividade encontrada naquela nação no decorrer dos anos. Esse processo não foi certamente de mão única. Se o paisagista foi seduzido pelo mundo americano, também seduziu a sociedade daquele país, a ponto de receber algumas 
cobiçadas distinções: a Fine Arts Medal, em 1965, outorgada pelo American Institute of Architects na edição seguinte à que homenageou Henry Moore; o título de membro honorário conferido pela Florida Association of Landscape Architects (Flasla) em 1969; e a mostra retrospectiva Roberto Burle Marx: the unnatural art of the garden, idealizada pelo historiador William Howard Adams, em 1991, para o MoMA, de Nova York -, reconhecimento que nenhum outro arquiteto ou paisagista brasileiro receberam desde então. De certo, as ligações de Burle Marx com os Estados Unidos são um prato cheio que poderá render boas páginas em futuros estudos historiográficos.

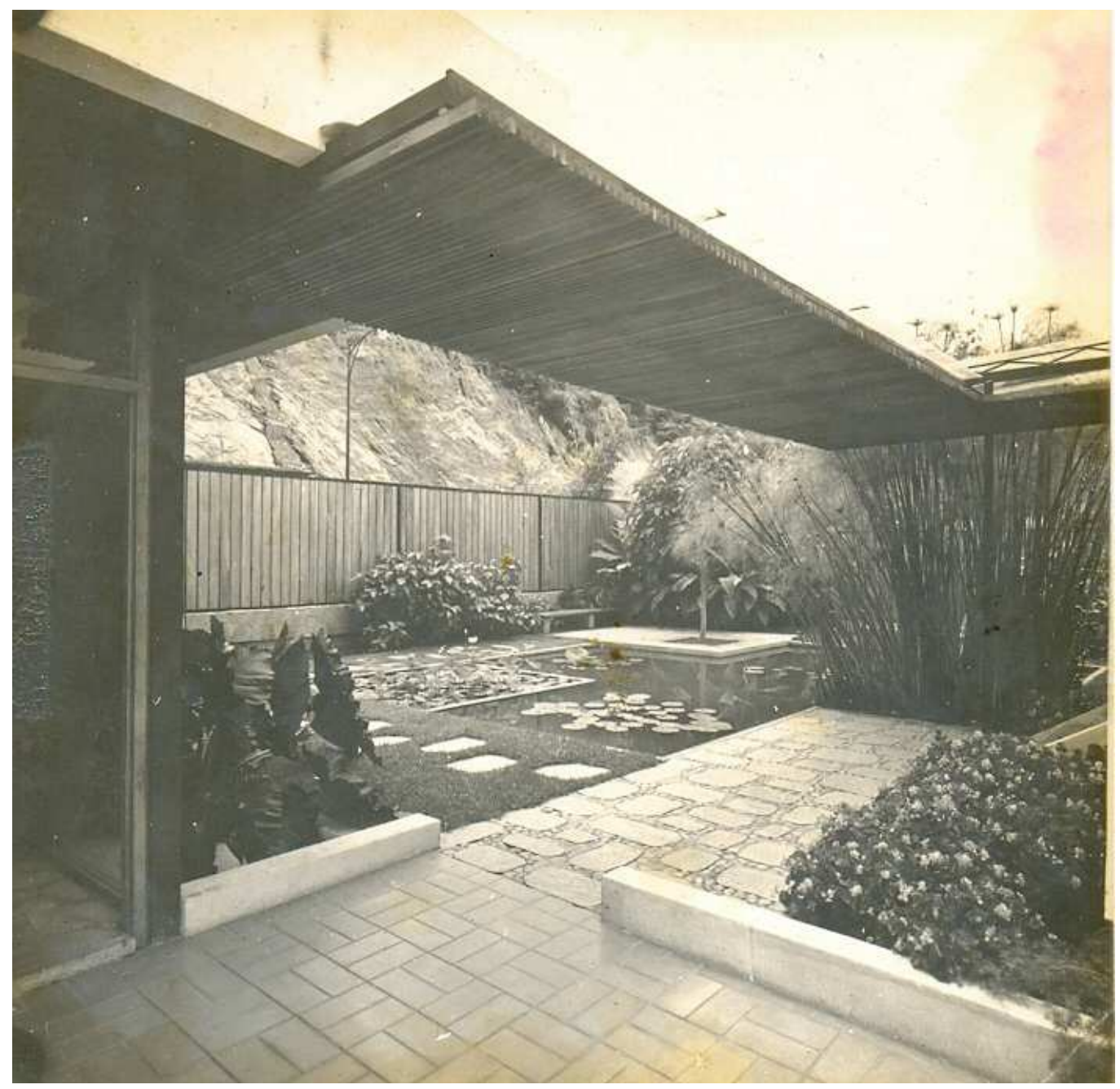

Figura 9a Jardins da residência Inocente Palacios, nos arredores de Caracas. Fonte: Acervo Escritório de Paisagismo Burle Marx.

A internacionalização das relações profissionais comparece em outro grupo de cartas, em que são mencionadas as obras e a clientela na Venezuela entre 1956 e 1965. Nesse país, Burle Marx levou adiante seu maior conjunto projetual além das fronteiras brasileiras, justificando inclusive a abertura de uma filial de seu escritório por lá, sob 
a responsabilidade dos sócios Fernando Tábora e John Stoddart. A lista de trabalhos não era nada desprezível, embora nem todos chegaram a ser implantados - mais de trinta projetos, entre clubes, parques, urbanizações, jardins residenciais, paisagismo de edifícios de escritórios, de hotéis e de hospitais, distribuídos em Caracas, Naiguatá, Maracaibo, Cumana, La Vega, Miranda e Valencia. O rol dos contratantes locais não era nada singelo, incluindo do governo central até nomes proeminentes das fortunas nacionais, como o empreendedor imobiliário e mecenas cultural Inocente Palacios e o industrial e empresário das comunicações Diego Cisneros. Foi um caso singular de concentração de encargos de um profissional brasileiro em um único país estrangeiro, implicando ainda na execução daquele que se tornaria um dos mais significativos espaços de recreação urbana nas Américas da segunda metade do século XX - o parque del Este.

Algumas explicações e conjecturas para o surgimento dessa demanda surgem em meio aos papéis, como neste trecho, escrito em 18/9/1956, para a crítica inglesa Claude Vincent, em que o paisagista identificava os desdobramentos de sua atuação como uma das primeiras divulgadoras internacionais da produção burlemarxiana:

Fomos extraordinariamente bem recebidos em Caracas e creio que terei uma ótima possibilidade de realização de jardins, parques etc. ligados à boa arquitetura. A compreensão e a boa vontade dos arquitetos foram enormes, sobretudo em relação à minha pessoa. Se hoje estou colhendo resultados fora do Brasil, é devido à divulgação do meu trabalho em revistas estrangeiras que você e outros têm feito.

Em outra passagem, na qual dava notícias diretamente de Caracas ao irmão GuiIherme Siegfried, em 8/2/1957, associava o respaldo local à admiração exercida por seu trabalho entre as elites progressistas e o grupo de arquitetos modernos daquele país:

Desde que chegamos não fizemos outra coisa a não ser contato com pessoas que querem trabalhos e, ao mesmo tempo, procuramos normalizar o que já tínhamos deixado alinhavado. Esperamos que tudo aconteça como havíamos imaginado, ou melhor, que a coisa se realize além de nossas expectativas. Estou convencido que temos que aproveitar esta grande chance e o prestígio que desfruto aqui.

Seguindo-se a narrativa das cartas, depreende-se que o parque del Este era um dos encargos mais aludidos nos parágrafos que tratam das obras venezuelanas. $E$ isso não causa surpresa, tendo em vista não somente sua importância na folha local de serviços, mas por conta dos impasses surgidos desde a fase inicial de sua concepção. Economia afluente baseada na exploração de petróleo, a Venezuela almejava seu ingresso no rol das nações mais prósperas e desenvolvidas do continente americano, e, como estratégia para promovê-la aos olhos externos, seus governantes decidiram investir na preparação da Exposição Internacional de Caracas de 1960, em que seriam 
apresentados as conquistas materiais e os avanços da modernidade no país. Nesse contexto, fez-se a contratação de Roberto Burle Marx, em 1956, para idealizar um projeto paisagístico que the serviria de suporte. Mas nem bem transcorreram dois anos, a queda do governo Pérez Jiménez motivou a interrupção dos trabalhos projetuais, e, após idas e vindas, prevaleceu a decisão de fazer um parque metropolitano no mesmo sítio. Tal mudança levou à revisão do que já estava desenhado, com a manutenção de alguns elementos-chave da solução espacial que poderiam ser aproveitados no novo programa, caso dos pátios temáticos delimitados por muros.

Realizadas no calor da hora, as apreciações de Burle Marx expõem as dinâmicas e as tensões que acompanharam a realização desse e de outros trabalhos na Venezuela. No caso do parque del Este, seus comentários melhor esclarecem informações já disponíveis e apontam divergências com passagens do relato memorialístico de meio século depois, de Fernando Tábora, em Dos parques, un equipo, editado em 2007, e mesmo no volume Roberto Burle Marx in Caracas: parque del Este, 1956-1961, de Anita Berrizbeitia, publicado em 2005, que não incorpora e tampouco menciona a extensa documentação projetual e escrita preservada na sede brasileira do escritório do paisagista. Tudo isso merece ser discutido em não apenas um, mas em vários futuros artigos.

\section{AFINAL EM BRASÍLIA}

A perspectiva de novas obras em paisagismo e artes visuais, o registro das que estavam em preparação e o informe sobre as recém-concluídas são motes tratados não apenas nesta ou naquela carta, mas que atravessam de ponta a ponta o acervo epistolar. Atentando-se para os trechos a respeito da atividade profissional, é possível extrair justificativas para intrigantes questões, como o distanciamento de Burle Marx, então respeitada autoridade do paisagismo nacional, tanto da fase de planejamento quanto de implementação de Brasília. Escrevendo a Walter, em 3/10/1956, relatava que "[...] a situação política não é das melhores, porquanto não estou nas graças de Juscelino pelo fato de ter reclamado, em outras épocas, dinheiro que me era devido". Anos depois, também em correspondência ao irmão mais velho, de 8/8/1960, fazia saber mais pormenores que ainda obstruíam seu ingresso na nova capital:

Até agora, não tivemos trabalho em Brasília, em parte, pelas exigências e garantias possivelmente demasiadas nas propostas que fizemos e também por não estar nas graças do nosso presidente, que não me havia pago os trabalhos na época em que fora prefeito de Belo Horizonte.

O pivô da desavença com Kubitschek teria ocorrido pela não remuneração de algum ou alguns dos projetos de paisagismo realizados no bairro da Pampulha entre 1942 e 1945, gerando ressentimentos de ambos lados, que perdurariam por muito 
tempo. A partir de 1960, a notória ausência de intervenções de Burle Marx na capital federal parecia prestes a ser desbancada com a encomenda de propostas para - Parque Zoobotânico e a Esplanada dos Ministérios. No entanto, a materialização de ambas não foi adiante. Esse quadro de tentativas frustradas só foi alterado com os trabalhos para o ltamaraty, encomendados por Vladimir do Amaral Murtinho. Ao menos desde a metade da década de 1950, o paisagista e o diplomata estreitavam contatos profissionais e vínculos de amizade, mirando inicialmente a realização de mostras no exterior. Mas foi nas obras do ltamaraty que a parceria de trabalho entre eles atingiu seu ápice. Para o palácio da diplomacia brasileira, Burle Marx foi incumbido de realizar vários encargos, a começar pelos jardins externos e internos. $\bigcirc$ alcance e os desdobramentos dessa proposta foram salientados pelo paisagista em carta a Hamerman, de 17/3/1967:

[...] ontem vim de Brasília, onde terminei o jardim do Ministério das Relações Exteriores. É um jardim que, na minha carreira, tem uma importância enorme. É um jardim aquático, no qual há um grande número de plantas da região. A solução como jardim aquático é nova, sobretudo se estabeleço um paralelo com o jardim aquático de Casa Forte, em Pernambuco, meu primeiro jardim aquático. Os volumes distribuídos no lago ou tanque que circunda o Ministério das Relações Exteriores estão ligados ao ritmo dos arcos que caracteriza o prédio. Naturalmente, este jardim só vai mostrar as intenções depois que as plantas crescerem. $\bigcirc$ jardim interno se liga ao jardim externo. Cobri tubos com xaxim e plantei filodendros, antúrios e outras plantas epífetas. É verdade que o efeito é de primeira qualidade e Oscar Niemeyer gostou muito. Isso faz com que muita gente sem opinião definida e que encontrou uma série de erros ache agora tudo extraordinário. $\bigcirc$ jardim do terraço foi um problema difícil, pois não havia como dispor muita terra nos canteiros e, devido a isso, utilizei uma série de plantas saxícolas e com capacidade de adaptação a pouca terra. Quero ver se faço fotografias dos planos, a fim de que você possa inserir no futuro livro; creio que será um marco na minha obra. As plantas foram fornecidas por nós, o que nos deu a possibilidade de empregar o material que dispúnhamos no sítio. Plantas aquáticas foram coletadas e selecionadas especialmente para este jardim.

No entanto, o paisagismo do ltamaraty, que futuramente será capa de importante livro assinado por Flávio Motta, não era a única obra de excepcional qualidade que Burle Marx desenhou para a instituição. Há que se lembrar igualmente a tapeçaria- mural destinada ao salão de banquetes, no terceiro andar da edificação. Trabalho de idealização e fatura complexas, pelas grandes dimensões que envolvia, foi assunto em várias correspondências que explanam desde os momentos de sua criação em 1965, passando pela execução, em 1966, dos moldes em tamanho natural, no formato de cinco cartões de 5,2 metros de comprimento por 4,2 metros de altura, até propriamente a urdidura, entre 1966 e 1967. Após consultas a fim de verificar quem teria condições 
de executá-la tanto no Brasil quanto no exterior - caso da Fábrica de Tapetes Beiriz, em Portugal -, prevaleceu a escolha do Atelier Douchez-Nicola, de São Paulo.

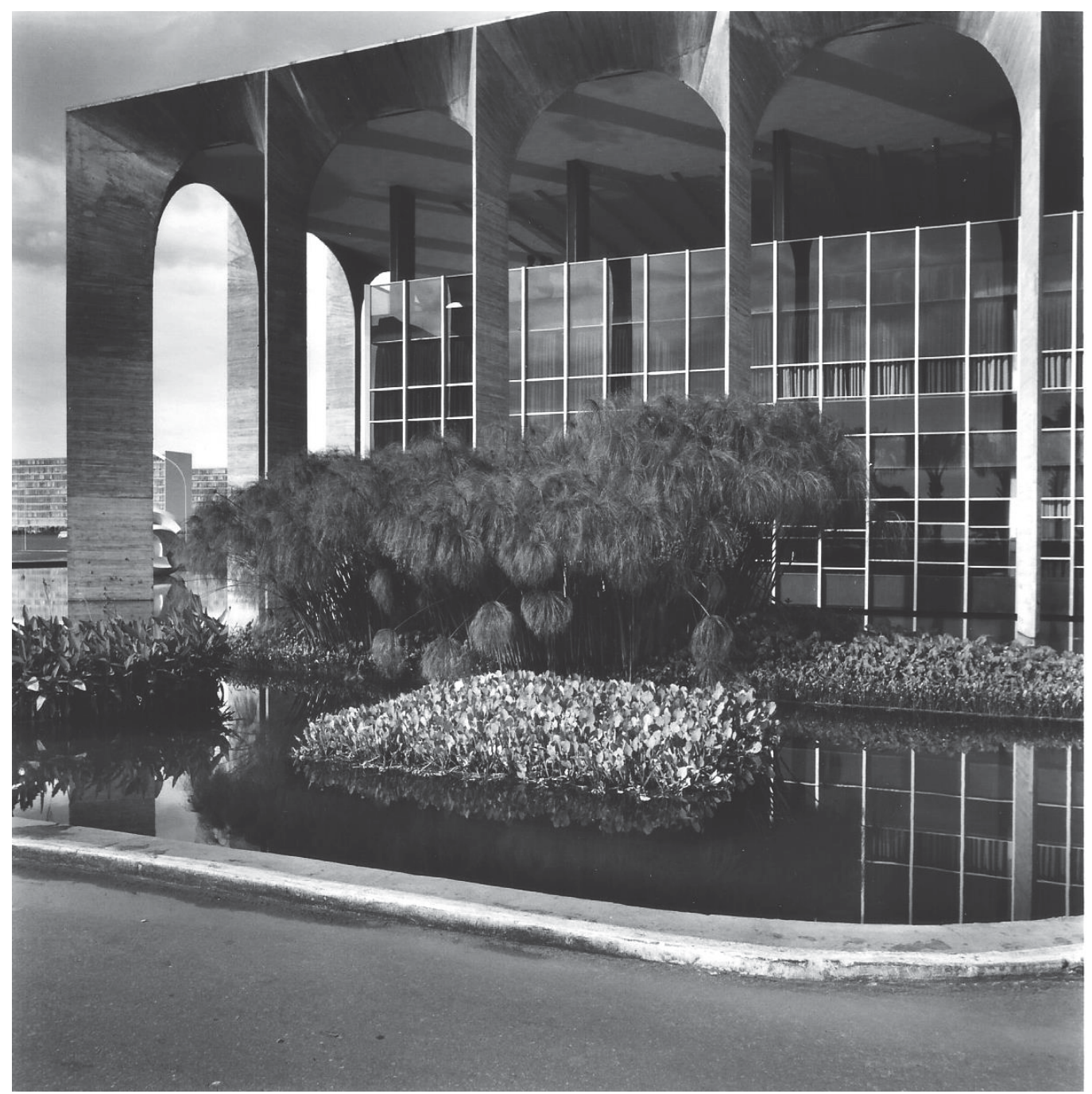

Figura 10 Jardins externos do Palácio do Itamaraty, em Brasília. Foto: Marcel Gautherot, Instituto Moreira Salles.

Além da grande tapeçaria, Burle Marx seguia com outras incumbências do Itamaraty, especialmente obras de arte efêmera, como as decorações dos eventos oficiais a partir de arranjos florais e vegetais - capítulo ainda a demandar a atenção dos estudiosos. Geralmente, eram preparadas com flores, frutos e folhagens cultivados no sítio Santo Antônio da Bica, levadas de carro até Brasília e montadas pelo paisagista com a ajuda de um ou dois de seus assistentes. Haruyoshi Ono recordava-se de participar de algumas dessas decorações, indo na dianteira para a capital federal, a fim de iniciá-las, e aguardando a chegada do paisagista para concluí-las. Uma das mais 
interessantes foi a organizada para a recepção da rainha Elizabeth II, da Inglaterra, em sua primeira viagem a Brasília e ao Brasil, em 1968. Pelos registros fotográficos de Marcel Gautherot, é possível conferir a inventividade e a beleza dos arranjos feitos nessa ocasião que, empregando plantas brasileiras e tropicais, rivalizavam francamente com a magnificência do vestuário da rainha e suas joias valiosas e raras.

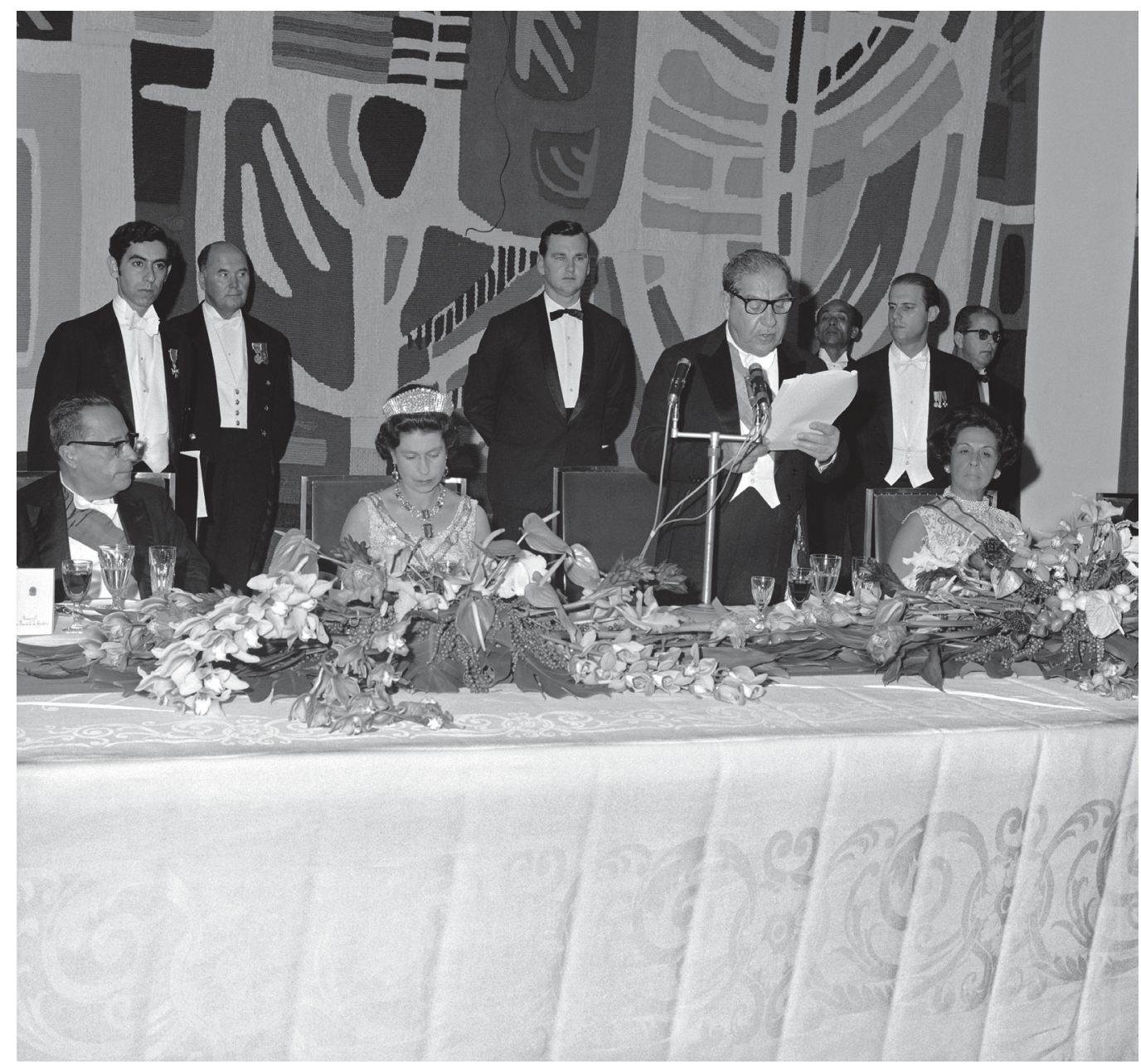

Figura 11 Arranjos vegetais de Burle Marx preparados para a recepção em homenagem à rainha Elizabeth II, no Palácio do Itamaraty, em 1968.

Foto: Marcel Gautherot, Instituto Moreira Salles.

\section{JULGAR PELAS CARTAS}

Por que Roberto Burle Marx, que mantinha uma rotina diária tão sobrecarregada por diversas atividades, reuniões profissionais e viagens de trabalho, dedicava-se também a escrever e ler correspondências? Por que ele e sua equipe se empenharam em organizar e conservar a maior parcela do arquivo epistolar ao longo dos anos? Quem 
eram os interlocutores de suas missivas, espalhados pelo Brasil e pelo mundo afora? Quais os assuntos tratados em seus papéis, que, somando as correspondências ativa e passiva, suplantam a marca de 2 mil cartas? Em que medida os conteúdos de suas missivas ensejam melhor conhecer episódios importantes e obras-chave de sua maturidade intelectual e profissional? Qual a relevância desses documentos para a história do paisagismo moderno brasileiro e internacional?

Ao longo das páginas anteriores, essas interrogações serviram de norte para uma apreciação inicial sobre as potencialidades do acervo epistolar de Burle Marx, visando a reexaminar seu legado artístico e paisagístico. Vale, aqui, a mensagem de Émile Zola, que, enfatizando o alcance desse tipo de escritos pessoais, dizia a Jean-Baptistin Baille, em correspondência de 2/6/1860: "Só podes julgar-me pelas minhas cartas, por essas cartas tão queridas nas quais sonho, nas quais vivo." (ZOLA, 1860 apud DIAZ, 2016, p. 86)

\section{REFERÊNCIAS BIBLIOGRÁFICAS}

DIAZ, Brigitte. O gênero epistolar ou o pensamento nômade: formas e funções da correspondência em alguns percursos de escritores no século XIX. São Paulo: Edusp, 2016.

DOURADO, Guilherme Mazza. Modernidade verde: jardins de Burle Marx. São Paulo: Senac; Edusp, 2009.

Folhas em movimento: cartas de Burle Marx. Relatório de Pesquisa em Pós-Doutorado. São Paulo: FAUUSP, 2014.

MARX, Roberto Burle. Carta para Thomas Church. Rio de Janeiro, 5 mar. 1949. (Datilografada e manuscrita).

. Carta para Garrett Eckbo. Rio de Janeiro, 8 abr. 1950.

Carta para Walter Burle Marx. Rio de Janeiro, 18 ago. 1955.

Carta para Claude Vincent. Rio de Janeiro, 18 set. 1956.

. Carta para Walter Burle Marx. Rio de Janeiro, 3 out. 1956.

. Carta para Guilherme Siegfried Marx. Caracas, fev. 1957.

. Carta para Walter Burle Marx. Rio de Janeiro, 8 ago. 1960.

Carta para Conrad Hamerman. Rio de Janeiro, 18 nov. 1964.

Carta para Alex Cirulizza. Rio de Janeiro, 12 jan. 1965.

. Carta para Alex Cirulizza. Rio de Janeiro, 20 ago. 1965.

. Carta para John Stoddart e Fernando Tábora. Rio de Janeiro, 17 nov. 1965.

. Carta para Meta Schück. Rio de Janeiro, 12 nov. 1965.

. Carta para Walter Burle Marx. Rio de Janeiro, 1 dez. 1965.

Carta para Conrad Hamerman. Rio de Janeiro, 17 mar. 1967.

. Carta para Walter Burle Marx e Fannie. Rio de Janeiro, 13 set. 1967.

. Carta para Walter Burle Marx e Fannie. Rio de Janeiro, 31 jan. 1968.

. Carta para Walter Burle Marx. Rio de Janeiro, 16 jun. 1970.

Carta para Raimundo Moniz de Aragão, presidente do Conselho Federal de Cultura. Rio de Janeiro, 7 
mai. 1974.

Carta para Wolfgang Sauer. Rio de Janeiro, 4 nov. 1976.

Carta para Walter Burle Marx. Rio de Janeiro, 2 mai. 1977.

Carta para Leandro Silva Delgado e Júlia. Rio de Janeiro, 7 nov. 1979.

Carta para Conrad Hamerman. Rio de Janeiro, 26 mar. 1990.

; TABACOW, José (Org.). Arte e paisagem: conferências escolhidas. São Paulo: Nobel, 1987.

MEZAN, Renato. As cartas de Freud. In: GALVÃO, Walnice Nogueira; GOTLIB, Nádia Batella (Orgs.). Prezado senhor, prezada senhora: estudos sobre cartas. São Paulo: Companhia das Letras, 2000, p. 159-173.

MOTTA, Flávio L. Roberto Burle Marx e a nova visão da paisagem. 3 ed. São Paulo: Nobel, 1986.

RESENDE, OHto Lara. Cartear é bem melhor. In: Bom dia para nascer: crônicas publicadas na Folha de S. Paulo. São Paulo: Companhia das Letras, 2011 , p. 230-232.

ROUANET, Sérgio Paulo. Apresentação. In: ROUANET, Sérgio Paulo (Coord.). Correspondência de Machado de Assis. Rio de Janeiro: ABL, tomo I, 2008, p. VII-XVII.

TÁBORA, Fernando. Dos parques, un equipo. Caracas: Embajada de Brasil en Venezuela/Norberto Odebrecht Constructora, 2007.

\section{AGRADECIMENTOS}

Nossos especiais agradecimentos a Haruyoshi Ono (em memória), Fátima Gomes e Isabela de Carvalho Ono, que permitiram o estudo do acervo epistolar de Burle Marx durante a elaboração do projeto de pós-doutorado Folhas em movimento: cartas de Burle Marx (2014). 